Indian J. Anim. Hlth. (2020), 59(1) : 78-84

DOI: $10.36062 /$ ijah.59.1.2020.78-84

\title{
EFFECT OF BYPASS FAT SUPPLEMENTATION ON PERFORMANCES IN CROSSBRED CATTLE DURING WINTER SEASON
}

\author{
J. HUSSIAN BUTT ${ }^{1}$, D. KONWAR ${ }^{1 *}$, B. BRAHMA ${ }^{1}$, A. KHAN ${ }^{1}$ AND R. K. SHARMA ${ }^{2}$
}

IDivision of Livestock Production and Management, Sher-e-Kashmir University of Agriculture Sciences and Technology - Jammu, R. S. Pura, Jammu-181 102, India

${ }^{2}$ Division of Animal Nutrition, Sher-e-Kashmir University of Agriculture Sciences and Technology - Jammu, R. S. Pura, Jammu-181 102, India

To study the effect of bypass fat supplementation on physiological, haemato-biochemical, behavioural parameters and milk production of crossbred cattle during winter (12 weeks), 12 crossbred dairy cattle, $4-5$ years old, $423 \pm 5.9$ kg average body weight and producing $12.5 \pm 0.3 \mathrm{~kg} / \mathrm{d}$ of milk were randomly divided into two groups with six animals each group. Animals in the control group $\left(T_{1}\right)$ were fed a basal diet while the animals in the treatment group $\left(T_{2}\right)$ were fed the basal diet supplemented with a bypass fat @ $250 \mathrm{gm} / \mathrm{animal} / \mathrm{day}$. The mean of minimum temperature, maximum temperature, wind velocity and wind chill temperature $(W C T)$ ranged from $9.9 \pm 0.5$ to $17.9 \pm 0.8^{\circ} \mathrm{C}, 21.9 \pm 0.7$ to $26.9 \pm 0.5^{\circ} \mathrm{C}, 2.4 \pm 0.4$ to $4.1 \pm 0.5$ $\mathrm{km} / \mathrm{h}$ and $7.9 \pm 0.5$ to $16.0 \pm 0.8^{\circ} \mathrm{C}$, respectively. Supplementation of bypass fat significantly $(\mathrm{P}<0.05)$ increased the rectal temperature of $\mathrm{T}_{2}\left(36.3 \pm 0.1^{\circ} \mathrm{C} ; 38.3 \pm 0.1^{\circ} \mathrm{C}\right)$ compared with the $\mathrm{T}_{1}\left(36.1 \pm 0.1^{\circ} \mathrm{C} ; 37.8 \pm 0.1^{\circ} \mathrm{C}\right)$ at both $6: 00 \mathrm{~h}$ and $14: 00 \mathrm{~h}$ but did not significantly affect the respiration rate or pulse rate. The overall mean milk yield was higher $(P<0.05)$ in $T_{2}$ $(12.8 \pm 0.2 \mathrm{~kg} / \mathrm{d})$ than the $T_{1}(11.3 \pm 0.2 \mathrm{~kg} / \mathrm{d})$. Haemoglobin, packed cell volume, erythrocytic sedimentation rate, aspartate aminotransferase, alanine aminotransferase, superoxide dismutase, glutathione peroxidase, dry matter intake, water intake and rumination number did not differ significantly between the $T_{1}$ and $T_{2}$ groups. Thus, it is concluded that supplementation of bypass fat had beneficial effect on crossbred dairy cattle by maintaining the normal rectal temperature and preventing decline in milk production during winter.

Key words: Bypass fat, Crossbred cattle, Haemato-biochemical parameters, Milk production, Physiological parameters

Livestock are adversely affected by the detrimental effects of extreme weather leading to decreased production and reproduction efficiency (Sejian, 2013). The acceptable thermoneutral range varies with breed and production level. The crossbred cattle are more adapted to warm climate than cold climate (McManus et al., 2014) and have a comfort zone of $18.3-23.7^{\circ} \mathrm{C}$ (Yasothai, 2014) while the zone of comfort for Indian cows is $10-26.7^{\circ} \mathrm{C}$ (Prasad and Neeraj, 2010).
Cold stress causes reduction in growth rate, feed conversion efficiency and milk secretion in lactating cows causing economic loss to the dairy farmers. Apart from lower critical temperature, cold stress is also described with the help of the Wind Chill Temperature (WCT) index (Angrecka and Herbut, 2015). WCT is the actual temperature felt by the animal (Agarwal and Upadhya, 2013) and it takes into account both air temperature and the effect of wind chill. When the ambient temperature is 
between the lower critical temperature (LCT) and the upper critical temperature (UCT) i.e., thermo-netural zone, the animal has to invest only a minimum of energy in maintaining its body temperature (Silanikove, 2000). But, when the ambient temperature falls below the LCT, the animal is required to increasingly invest metabolic energy for heat production and the energy available for production diminishes. Unless additional food energy is provided to compensate for increased energy demand in cold environment, availability of metabolizable energy for productive process would be limited.

Feeding of bypass fat can enhance the energy density of the diet (Krishna Mohan and Reddy, 2009) to meet the energy requirement and alleviate problems of negative energy balance (Chalupa et al., 1985). Supplementation of fat to grazing cows increased milk production by $4.5 \%(1.0 \mathrm{~kg} / \mathrm{d})$ compared to control cow (Schroeder et al., 2004), increased body weight gain of pre weaned caves fed during mild winter (Litherland et al., 2014) and also increased the body temperature of cattle exposed to cold conditions (Gaughan and Mader, 2009).

In Jammu the winter temperature occasionally fall below $4^{\circ} \mathrm{C}$, possibly leading to cold stress in dairy cattle. Research reports on feeding of bypass fat to ameliorate the effect of cold stress are limited. Therefore, the present study was conducted to evaluate the effect of dietary bypass fat supplementation on physiological and haemato-biochemical parameters, dry matter intake, water intake, rumination number and milk production of crossbred dairy cattle during winter.

\section{MATERIALS AND METHODS}

The study was carried out at the Division of Livestock Production and Management, Shere-Kashmir University of Agriculture Sciences and Technology, Jammu, India. The protocol of experiment was approved by the Committee for the Purpose of Control and Supervision of
Experiments on Animals (CPCSEA) (No. 862/ GO/Re-SL/Bi-L/04). Twelve lactating crossbred cattle, in $3^{\text {rd }}$ lactation, average body weight of $423 \pm 5.9 \mathrm{~kg}$ and producing $12.5 \pm 0.3 \mathrm{~kg}$ of milk per day were selected and divided into two groups $\left(T_{1}\right.$ and $\left.T_{2}\right)$ consisting 6 animals in each group in a Randomised Block Design. The animals of $\mathrm{T}_{1}$ group was fed only on basal diet and served as control animals while the animals of $\mathrm{T}_{2}$ group were fed on basal diet supplemented with bypass fat @ $250 \mathrm{gm} / \mathrm{animal} / \mathrm{day}$. Bypass fat manufactured by Guru Anand Dev Veterinary and Animal Science University, Ludhiana was used for the experiment. It comprised of blend of calcium salt of rice bran fatty acids with vitamins. It has $84 \%$ bypass fat, $7-8 \%$ calcium, vitamin $\mathrm{A}, \mathrm{D}_{3}, \mathrm{E}$, biotin, rumen protected niacin and rumen protected choline. Bypass fat was fed mixed with concentrate ration once a day in the evening. The study was conducted for a period of 12 weeks from December, 2017 to February, 2018 after an adaptation period of 2 weeks. All the animals were dewormed with broad spectrum anthelmintic before the beginning of the trial and maintained in a hygienic condition with uniform management practices throughout the experiment.

Housing and feeding management: Animals were housed in well-ventilated brick cemented house with cemented anti-slippery floor and gable roof type. The animals remained in the shed throughout the day and night. During extreme winter the windows were covered with curtains of plastic sheets. Animals were fed twice daily (early noon and evening) with chopped rice straw, wheat straw and green forages fed ad lib and concentrate mixture @ $5-6 \mathrm{~kg} / \mathrm{animal} /$ day. The ingredients of concentrate mixture were crushed maize $(40 \%)$, wheat bran (37\%), groundnut cake $(20 \%)$, mineral mixture (2\%) and salt (1\%). The feeding standard of NRC (2001) was followed. Proximate composition of feeds and fodders were done as per the methods of AOAC (1990) and presented in Table 1. 
Table 1. Proximate composition of feed and fodder (\% on DM basis)

\begin{tabular}{lccccccc}
\hline \multicolumn{1}{c}{ Attributes \% } & $\begin{array}{c}\text { Wheat } \\
\text { straw }\end{array}$ & $\begin{array}{c}\text { Rice } \\
\text { straw }\end{array}$ & $\begin{array}{c}\text { Green } \\
\text { berseem }\end{array}$ & $\begin{array}{c}\text { Green } \\
\text { oat }\end{array}$ & $\begin{array}{c}\text { Concentrate Attributes } \\
\text { mixture }\end{array}$ & $\begin{array}{c}\text { Wheat } \\
\text { straw }\end{array}$ \\
\hline Dry matter (fresh basis) & 93.0 & 93.2 & 16.1 & 28.0 & 95.9 & 93.0 & 93.2 \\
Crude protein & 4.3 & 3.0 & 15.4 & 9.5 & 22.5 & 4.3 & 3.0 \\
Crude fiber & 39.9 & 37.9 & 26.3 & 24.4 & 7.7 & 39.9 & 37.9 \\
Ether extract & 0.7 & 0.9 & 2.6 & 2.7 & 3.5 & 0.7 & 0.9 \\
Total ash & 9.2 & 17.4 & 12.5 & 9.3 & 7.1 & 9.2 & 17.4 \\
Acid insoluble ash & 5.9 & 6.8 & 3.5 & 5.4 & 2.1 & 5.9 & 6.8 \\
Nitrogen free extract & 93.0 & 93.2 & 16.1 & 28.0 & 95.9 & 93.0 & 93.2 \\
\hline
\end{tabular}

Microclimatic variables: Maximum and minimum temperature was recorded by using thermometer $\left(\right.$ Six's $\left.^{\circledR}\right)$ in degree Celsius $\left({ }^{\circ} \mathrm{C}\right)$ at 06:00 h daily. Wind velocity was measured with the help of anemometer at 06:00 h daily and recorded as $\mathrm{km} / \mathrm{h}$. The WCT $\left({ }^{\circ} \mathrm{C}\right)$ was calculated as per Tucker et al. (2007), by using the following equation:

WCT index $=13.2+0.6215 \mathrm{~T}_{\text {air }}-13.17 \mathrm{~V}^{0.16}+$ $0.3965 \mathrm{~T}_{\text {air }} \mathrm{V}^{0.16}$

Where, (T)is the temperature of the air and (V) is the velocity of wind.

Physiological parameters: Physiological variables $v i z$. , respiratory rate (RR; breaths/minute), pulse rate (beats/minute) and rectal temperature $\left({ }^{\circ} \mathrm{C}\right.$; RT) of individual animals were recorded twice daily in the morning at 06:00 $\mathrm{h}$ and afternoon at 14:00 $\mathrm{h}$.

Haemato-biochemical parameters: Blood samples $(10 \mathrm{~mL} /$ animal $)$ were collected at monthly interval from the jugular vein using two different anticoagulant coated vacutainers. Ethylene diaminetetra-acetic acid containing blood was used for the estimation of haematological parameters viz., haemoglobin $(\mathrm{Hb})$, packed cell volume (PCV) and erythrocytic sedimentation rate (ESR) by routine haematological methods. Plasma aspartate amino transferees (AST) and alanine amino transferase (ALT) activities were determined using automated biochemistry analyser. Erythrocyte lysate was prepared on the same day for the analysis of oxidative enzymes viz., glutathione peroxidise (GPx) by the method of Hafeman et al. (1974) and superoxide dismutase (SOD) using method of Marklund and Marklund (1974). Blood glucose level was estimated using digital glucometer (Dr. Morepen BG-03) at the time of blood collection.
Milk Yield: Milk yield from individual animals were recorded twice daily i.e. 06:00 $\mathrm{h}$ and 17:00 $\mathrm{h}$ by a weighing machine.

Dry matter intake, water intake and rumination number: Dry matter intake of the individual animal was recorded at monthly interval. The amounts of feed were weighed before offering and residue were collected on next morning. The feed intake was calculated (on dry matter basis) by subtracting the amount of residue left from the amount of total feed offered. Similarly the water intake was estimated by subtracting the amount of residue left from the amount of total water offered. Rumination number (number/5minute) was calculated by abdominal palpation method.

Statistical Analysis: Experimental data were analyzed by one way ANOVA as per the method described by Snedecor and Cochran (1994) using SPSS16.

\section{RESULTS}

Microclimatic variables: The mean of minimum temperature, wind velocity and wind chill temperature recorded at 6:00 $\mathrm{h}$ (Table 2) during the experiment ranged from $9.9 \pm 0.5$ to $17.9 \pm 0.8^{\circ} \mathrm{C}, 21.9 \pm 0.7$ to $26.9 \pm 0.5^{\circ} \mathrm{C}, 2.4 \pm 0.4$ to $4.1 \pm 0.5 \mathrm{~km} / \mathrm{h}$ and $7.9 \pm 0.5$ to $16.0 \pm 0.8^{\circ} \mathrm{C}$. The mean WCT decreased to minimum in the $6^{\text {th }}$ week of experiment then increased gradually.

Physiological parameters: The mean RT recorded at 06:00 $\mathrm{h}$ were sub normal in both $\mathrm{T}_{1}$ and $T_{2}$ throughout the experiment and within the normal range at 14:00 h. Supplementation of 
bypass fat significantly $(\mathrm{P}<0.05)$ increased overall mean $\mathrm{RT}$ in $\mathrm{T}_{2}\left(36.3 \pm 0.1^{\circ} \mathrm{C}, 38.3 \pm 0.1^{\circ} \mathrm{C}\right)$ compared with the $\mathrm{T}_{1}\left(36.1 \pm 0.1^{\circ} \mathrm{C}, 37.8 \pm 0.1^{\circ} \mathrm{C}\right)$ at both 6:00 and 14:00 $\mathrm{h}$ (Table 3). The overall mean RR (Table 3) was higher and the PR (Table 3) lower in $T_{2}$ over $T_{1}$ at both 6:00 h and 14:00 h but no significant differences were observed between $T_{1}$ and $T_{2}$.

Haemato-biochemical parameters: The overall mean of $\mathrm{Hb}, \mathrm{PCV}$, and ESR in $\mathrm{T}_{1}$ and $\mathrm{T}_{2}$ (Table 4) did not show significant differences. Supplementation of bypass fat lowered the mean values of oxidative enzymes SOD and GPX, and, plasma AST and ALT (Table 4) but no significant difference between their mean were observed.
Blood glucose level (Table 4) was not significant.

Milk production: There was a trend of decrease in milk yield upto the mid of experiment and than an increasing trend was observed till the end of the experiment. Significantly $(\mathrm{P}<0.05)$ higher milk yield was observed in $T_{2}$ than $T_{1}$ group from $2^{\text {nd }}$ week of the trial (Table 5). The overall mean milk production (Table 5) of $\mathrm{T}_{2}(12.8 \pm 0.2 \mathrm{~kg} / \mathrm{d})$ was also significantly higher $(\mathrm{P}<0.05)$ than $\mathrm{T}_{1}(11.3 \pm 0.2 \mathrm{~kg} / \mathrm{d})$.

Dry matter intake, water intake and rumination number: The dry matter intake, water intake and rumination number (Table 5) did not differ significantly.

Table 2. Micro climatic variables during the experimental period

\begin{tabular}{lccccc}
\hline Period & Week & $\begin{array}{c}\text { Minimum } \\
\text { temperature }\left({ }^{\circ} \mathbf{C}\right)\end{array}$ & $\begin{array}{c}\text { Maximum } \\
\text { temperature }\left({ }^{\circ} \mathbf{C}\right)\end{array}$ & $\begin{array}{c}\text { Wind } \\
\text { velocity }(\mathbf{k m} / \mathbf{h})\end{array}$ & $\begin{array}{c}\text { WCT } \\
\left({ }^{\circ} \mathbf{C}\right)\end{array}$ \\
\hline Dec & 1 & $16.0 \pm 0.7$ & $26.0 \pm 0.5$ & $2.4 \pm 0.4$ & $14.8 \pm 0.8$ \\
& 2 & $15.4 \pm 1.2$ & $23.0 \pm 1.0$ & $4.1 \pm 0.5$ & $13.3 \pm 1.4$ \\
& 3 & $16.7 \pm 0.5$ & $25.1 \pm 0.6$ & $3.0 \pm 0.3$ & $15.2 \pm 0.7$ \\
& 4 & $14.7 \pm 0.3$ & $24.6 \pm 0.7$ & $2.9 \pm 0.3$ & $13.1 \pm 0.3$ \\
\hline Jan & 5 & $12.1 \pm 0.5$ & $21.9 \pm 0.7$ & $2.6 \pm 0.2$ & $10.5 \pm 0.6$ \\
& 6 & $9.9 \pm 0.5$ & $22.7 \pm 0.6$ & $2.7 \pm 0.3$ & $7.9 \pm 0.5$ \\
& 7 & $10.3 \pm 0.8$ & $24.9 \pm 0.6$ & $2.5 \pm 0.3$ & $8.6 \pm 0.8$ \\
& 8 & $11.7 \pm 0.4$ & $23.1 \pm 0.8$ & $3.1 \pm 0.3$ & $9.7 \pm 0.4$ \\
\hline Feb & 9 & $13.7 \pm 0.6$ & $23.9 \pm 0.7$ & $2.9 \pm 0.2$ & $11.9 \pm 0.8$ \\
& 10 & $13.1 \pm 0.3$ & $25.9 \pm 0.3$ & $2.8 \pm 0.3$ & $11.4 \pm 0.3$ \\
& 11 & $16.3 \pm 0.9$ & $24.0 \pm 0.6$ & $3.4 \pm 0.5$ & $14.7 \pm 0.8$ \\
& 12 & $17.9 \pm 0.8$ & $26.9 \pm 0.5$ & $3.0 \pm 0.5$ & $16.0 \pm 0.8$ \\
\hline
\end{tabular}

Table 3: Physiological parameters of experimental crossbred cattle

\begin{tabular}{lcccccc}
\hline Attributes & Time & Group & $\begin{array}{c}\text { December- } \\
\text { January }\end{array}$ & $\begin{array}{c}\text { January- } \\
\text { February }\end{array}$ & $\begin{array}{c}\text { February- } \\
\text { March }\end{array}$ & $\begin{array}{c}\text { Overall } \\
\text { mean }\end{array}$ \\
\hline Respiration & $6: 00 \mathrm{~h}$ & $\mathrm{~T}_{1}$ & $21.5 \pm 0.6$ & $19.7 \pm 0.4$ & $22.5 \pm 0.5$ & $21.7 \pm 0.6$ \\
rate & & $\mathrm{T}_{2}$ & $21.8 \pm 0.5$ & $20.2 \pm 0.5$ & $23.8 \pm 0.5$ & $22.1 \pm 0.5$ \\
\cline { 2 - 7 } (per minute) & $14: 00 \mathrm{~h}$ & $\mathrm{~T}_{1}$ & $27.0 \pm 0.7$ & $25.3 \pm 0.5$ & $27.6 \pm 0.7$ & $26.8+0.4$ \\
& & $\mathrm{~T}_{2}$ & $27.2 \pm 0.8$ & $25.9 \pm 0.7$ & $27.8 \pm 0.6$ & $27.1 \pm 0.4$ \\
\hline Pulse & $6: 00 \mathrm{~h}$ & $\mathrm{~T}_{1}$ & $62.3 \pm 0.7$ & $62.9 \pm 0.7$ & $61.0 \pm 0.6$ & $62.3 \pm 0.4$ \\
rate & & $\mathrm{T}_{2}$ & $62.5 \pm 0.7$ & $62.9 \pm 0.6$ & $61.0 \pm 0.6$ & $61.9 \pm 0.3$ \\
\cline { 2 - 7 } (beats/minute) & $14: 00 \mathrm{~h}$ & $\mathrm{~T}_{1}$ & $70.8 \pm 0.6$ & $71.9 \pm 0.7$ & $71.3 \pm 0.7$ & $71.3 \pm 0.2$ \\
& & $\mathrm{~T}_{2}$ & $70.6 \pm 0.6$ & $71.6 \pm 0.8$ & $70.8 \pm 0.8$ & $70.9 \pm 0.2$ \\
\hline Rectal & $6: 00 \mathrm{~h}$ & $\mathrm{~T}_{1}$ & $36.2 \pm 0.1$ & $35.6 \pm 0.1^{\mathrm{a}}$ & $36.4 \pm 0.1^{\mathrm{a}}$ & $36.1 \pm 0.1^{\mathrm{a}}$ \\
temperature & & $\mathrm{T}_{2}$ & $36.4 \pm 0.2$ & $35.9 \pm 0.4^{\mathrm{b}}$ & $36.9 \pm 0.4^{\mathrm{b}}$ & $36.3 \pm 0.1^{\mathrm{b}}$ \\
\cline { 2 - 7 }$\left({ }^{\circ} \mathrm{C}\right)$ & $14: 00 \mathrm{~h}$ & $\mathrm{~T}_{1}$ & $37.9 \pm 0.2$ & $37.6 \pm 0.2^{\mathrm{a}}$ & $37.9 \pm 0.2^{\mathrm{a}}$ & $37.8 \pm 0.1^{\mathrm{a}}$ \\
& & $\mathrm{T}_{2}$ & $38.2 \pm 0.2$ & $38.1 \pm 0.2^{\mathrm{b}}$ & $38.4 \pm 0.1^{\mathrm{b}}$ & $38.3 \pm 0.1^{\mathrm{b}}$ \\
\hline
\end{tabular}

Values with different superscript differ significantly $(\mathrm{P}<0.05)$ between the rows 
Table 4. Haemato-biochemical parameters of experimental crossbred cattle

\begin{tabular}{lcrrrrr}
\hline Attributes & Groups & December & January & February & March & Overall \\
\hline Haemoglobin & $\mathrm{T}_{1}$ & $10.6 \pm 0.3$ & $10.7 \pm 0.4$ & $11.3 \pm 0.3$ & $11.3 \pm 0.2$ & $10.9 \pm 0.2$ \\
(g/dL) & $\mathrm{T}_{2}$ & $10.6 \pm 0.2$ & $10.8 \pm 0.4$ & $11.3 \pm 0.2$ & $11.4 \pm 0.2$ & $10.9 \pm 0.2$ \\
\hline Packed cell volume & $\mathrm{T}_{1}$ & $31.7 \pm 0.5$ & $32.3 \pm 0.9$ & $32.5 \pm 0.9$ & $32.8 \pm 0.5$ & $31.9 \pm 0.4$ \\
$(\%)$ & $\mathrm{T}_{2}$ & $31.7 \pm 0.4$ & $32.3 \pm 0.5$ & $32.6 \pm 0.7$ & $32.8 \pm 0.5$ & $32.0 \pm 0.4$ \\
\hline Erythrocyte sedimentation rate & $\mathrm{T}_{1}$ & $2.9 \pm 0.2$ & $3.0 \pm 0.3$ & $3.3 \pm 0.2$ & $3.1 \pm 0.2$ & $3.0 \pm 0.1$ \\
(mm/24 h) & $\mathrm{T}_{2}$ & $3.0 \pm 0.3$ & $3.1 \pm 0.3$ & $3.3 \pm 0.3$ & $3.2 \pm 0.3$ & $3.1 \pm 0.1$ \\
\hline Aspartate amino transferase & $\mathrm{T}_{1}$ & $94.4 \pm 1.2$ & $90.6 \pm 1.3$ & $87.9 \pm 0.6$ & $85.2 \pm 0.7$ & $90.9 \pm 2.1$ \\
(IU/L) & $\mathrm{T}_{2}$ & $94.4 \pm 1.3$ & $90.5 \pm 1.1$ & $87.8 \pm 0.7$ & $85.2 \pm 0.9$ & $90.9 \pm 1.9$ \\
\hline Alanine amino transferase & $\mathrm{T}_{1}$ & $32.2 \pm 0.5$ & $34.1 \pm 0.8$ & $35.3 \pm 1.6$ & $37.1 \pm 0.9$ & $33.6 \pm 0.9$ \\
(IU/L) & $\mathrm{T}_{2}$ & $32.3 \pm 0.6$ & $34.2 \pm 0.9$ & $35.4 \pm 1.1$ & $37.3 \pm 0.7$ & $33.7 \pm 0.8$ \\
\hline Superoxide dismutase & $\mathrm{T}_{1}$ & $16.0 \pm 2.5$ & $15.5 \pm 1.7$ & $19.1 \pm 2.5$ & $19.4 \pm 2.5$ & $17.2 \pm 1.2$ \\
(U/mg of protein) & $\mathrm{T}_{2}$ & $16.2 \pm 2.1$ & $15.6 \pm 1.7$ & $19.2 \pm 2.2$ & $19.4 \pm 2.5$ & $17.4 \pm 1.1$ \\
\hline Glutathione peroxidase & $\mathrm{T}_{1}$ & $3.5 \pm 0.6$ & $2.5 \pm 0.8$ & $5.0 \pm 0.4$ & $5.7 \pm 0.5$ & $4.3 \pm 0.3$ \\
(U/mL) & $\mathrm{T}_{2}$ & $4.4 \pm 0.9$ & $2.7 \pm 05$ & $5.3 \pm 0.8$ & $5.8 \pm 0.7$ & $4.6 \pm 0.4$ \\
\hline Glucose & $\mathrm{T}_{1}$ & $68.3 \pm 0.8$ & $69.2 \pm 0.7$ & $69.8 \pm 0.6$ & $69.3 \pm 0.8$ & $68.8 \pm 0.4$ \\
(mg/dL) & $\mathrm{T}_{2}$ & $68.5 \pm 0.8$ & $69.3 \pm 05$ & $70.0 \pm 0.6$ & $69.5 \pm 0.4$ & $69.0 \pm 0.4$ \\
\hline
\end{tabular}

Table 5. Milk production $(\mathrm{kg} / \mathrm{d})$ of experimental crossbred cattle

\begin{tabular}{ccccc}
\hline Treatments & $\begin{array}{c}\text { December- } \\
\text { January }\end{array}$ & $\begin{array}{c}\text { January - } \\
\text { February }\end{array}$ & $\begin{array}{c}\text { February - } \\
\text { March }\end{array}$ & $\begin{array}{c}\text { Overall } \\
\text { mean }\end{array}$ \\
\hline $\mathrm{T}_{1}$ & $12.0 \pm 0.4^{\mathrm{a}}$ & $9.2 \pm 0.5^{\mathrm{a}}$ & $11.9 \pm 0.3^{\mathrm{a}}$ & $11.3 \pm 0.2^{\mathrm{a}}$ \\
$\mathrm{T}_{2}$ & $13.3 \pm 0.5^{\mathrm{b}}$ & $10.5 \pm 0.6^{\mathrm{b}}$ & $14.4 \pm 0.4^{\mathrm{b}}$ & $12.8 \pm 0.2^{\mathrm{b}}$ \\
\hline
\end{tabular}

Values with different superscript differ significantly $(\mathrm{P}<0.05)$ between the rows

\section{DISCUSSION}

Microclimatic variables: During the experimental period the WCT was $7.9 \pm 0.5$ to $16.0 \pm 0.8^{\circ} \mathrm{C}$ which was below the comfort zone of the crossbred dairy cattle as reported by Yasothai (2014). This result indicates stress in the animals during the period of experiment.

Physiological parameters: The increase or decrease in $\mathrm{RT}$ is an adaptive response of the animal to maintain homeothermy (Sabuncuoglu, 2004). Subnormal RT recorded in both $T_{1}$ and $\mathrm{T}_{2}$ at 6:00 $\mathrm{h}$ indicated stress in experimental animals. Supplementation of bypass fat significantly $(\mathrm{P}<0.05)$ increased overall mean $\mathrm{RT}$ in $\mathrm{T}_{2}$ over $\mathrm{T}_{1}$ at both 6:00 and 14:00 h. Higher RT in dietary fat supplemented group over the control group was also reported by Gaughan and
Mader (2009) and Moallem et al. (2010). Cho et al. (2014) also reported that high energy diet increased rectal temperature in cattle. The increase $(\mathrm{P}<0.05)$ in $\mathrm{RT}$ of $\mathrm{T}_{2}$ might be due higher energy density by bypass fat (NRC, 2001). Higher RR and lower PR were observed in $\mathrm{T}_{2}$ over $\mathrm{T}_{1}$ at both 6:00 $\mathrm{h}$ and 14:00 $\mathrm{h}$. But there was no significant difference between the mean values which indicated that supplementation of bypass fat has no significant effect on respiration rate and pulse rate.

Haemato-biochemical parameters: Supplementation of bypass fat did not exert any effect on haematological profile (Table 4). This was in agreement with Savsani et al. (2013). This revealed that supplementation of bypass fat did not exert any effect on haematological 
Table 6. Dry matter intake $(\mathrm{kg} / \mathrm{d})$, water intake $(\mathrm{L})$ and rumination number of experimental crossbred cattle

\begin{tabular}{lcrrrrr}
\hline Attributes & Group & December & January & February & March & Overall \\
\hline Dry matter intake & $\mathrm{T}_{1}$ & $12.8 \pm 0.6$ & $13.2 \pm 0.8$ & $13.4 \pm 0.5$ & $12.5 \pm 0.6$ & $12.2 \pm 0.3$ \\
& $\mathrm{~T}_{2}$ & $13.3 \pm 0.5$ & $13.3 \pm 0.6$ & $13.6 \pm 0.3$ & $13.3 \pm 0.9$ & $13.3 \pm 0.3$ \\
Water Intake & $\mathrm{T}_{1}$ & $46.2 \pm 1.6$ & $47.1 \pm 1.3$ & $46.3 \pm 1.4$ & $45.5 \pm 1.4$ & $46.2 \pm 0.6$ \\
& $\mathrm{~T}_{2}$ & $46.6 \pm 1.5$ & $47.3 \pm 1.3$ & $46.8 \pm 1.9$ & $45.9 \pm 1.7$ & $46.6 \pm 0.7$ \\
Rumination number & $\mathrm{T}_{1}$ & $8.7 \pm 0.5$ & $9.2 \pm 0.5$ & $8.8 \pm 0.3$ & $8.5 \pm 0.7$ & $8.6 \pm 0.3$ \\
(number/5 $\mathrm{min}$ ) & $\mathrm{T}_{2}$ & $8.8 \pm 0.5$ & $9.5 \pm 0.8$ & $9.2 \pm 0.4$ & $8.8 \pm 0.8$ & $8.9 \pm 0.3$ \\
\hline
\end{tabular}

profile. Supplementation of bypass fat had no significant effect on SOD, GPX, AST and ALT. Blood glucose level observed between bypass fat treated group and the control group was not significant. This finding is similar to the report of Ranjan et al. (2009). Contrary, significantly higher blood glucose level was reported by Waghmare et al. (2016) in bypass fat treated group.

Milk production: The trend of milk production corresponded with the WCT. The decrease in milk production might be due the fact that more energy is diverted for maintaining body temperature and less energy was available for milk production. Reduction in milk yield due to cold stress was also reported by Angrecka and Herbut (2015). Significant increase in milk yield by dietary supplementation of bypass fat is in accordance to the findings of Gowda et al. (2013) and Wadhwa et al. (2012) which may be attributed to the improved energy status due

\section{REFERENCES}

Agarwal A and Upadhya R, 2013. Heat stress and Animal Productivity. Springer, India, pp2, doi: 10.1007/978-81-322-0879-2

Angrecka S and Herbut P, 2015. Conditions for cold stress development in dairy cattle kept in free stall barn during severe frosts. Czech J Anim Sci, 60: 81-87

AOAC, 1990. Official Methods of Analalysis, 15 edn., (Eds. Kenneth Helrich) Association of Official Analytical Chemists, Inc., Suite 400, 2200 Wilson Boulevard, Arlington, Virginia 22201, USA to supplementation of bypass fat as stated by Naik et al. (2009).

Dry matter intake, water intake and rumination number: The dry matter intake, water intake and rumination number (Table 6) did not significantly differ. No significant effect in dry matter intake in bypass fat treated group is in accordance to Mudgal et al. (2012).

On the basis of the above observation, it is concluded that supplementation of dietary bypass fat at $250 \mathrm{~g}$ per day to lactating crossbred cattle increases the rectal temperature and the milk production and therefore can alleviate the negative effect of cold stress during winter.

\section{ACKNOWLEDGEMENT}

This study was supported by the funds of Science and Engineering Research Board, Department of Science and Technology, Government of India (Grant No.: EMR/2016/ 002845/AS).

Chalupa WB, Vecchiarelli B, Sklan D and Kronfeld DS, 1985. Response of rumen micro-organisms and lactating cows to calcium salts of long chain fatty acids. J Dairy Sci, 68: 110

Cho SM, Shim DT, Lee K, Seong AL, Yang JO et al., 2014. The influence of feed energy density and a formulated additive on rumen and rectal temperature in Hanwoo steers. Asian-Austr J Anim Sci, 27: 1652-1662

Gaughan JB and Mader TL, 2009. Effects of sodium chloride and fat supplementation on finishing steers exposed to hot and cold conditions. J Anim Sci, 87: 612-621 
Gowda NKS, Manegar A, Raghavendra A, Verma S, Maya G et al., 2013. Effect of protected fat supplementation to high yielding dairy cows in field condition. Anim Nutr Feed Technol, 13: $125-130$

Hafeman DG, Sunde RA and Hoekstra WG, 1974. Effect of dietary selenium on erythrocyte and liver glutathione peroxidase in the rat. J Nutr, 104(5): 580-587, doi: 10.1093/jn/104.5.580

Krishna Mohan DVG and Reddy YR, 2009. Role of bypass nutrients in small holder animal production. Proceeding of Animal Nutrition Association World Conference, New Delhi, India

Litherland DNL, Da Silva RJ, La Berge J, Schefers A and Kertz A, 2014. Supplemental fat for dairy calves during mild cold stress. J Dairy Sci, 97: 2980-2989

Marklund S and Marklund G, 1974. Involvement of the superoxide anion radical in the autoxidation of pyrogallol and a convenient assay for superoxide dismutase. European J Biochem, 47: 469-474

McManus CM, Louvandini H, Paim TP and Bernal FEM, 2014. Factors affecting heat tolerance in crossbred cattle in central Brazil. Ciência Anim Brasileira, 15: 152-158

Moallem U, Altmark G, Lehrer H and Arieli A, 2010. Performance of high yielding dairy cows supplemented with fat or concentrate under hot and humid climates. J Dairy Sci, 93: 3192-202

Mudgal V, Baghel RPS, Ganie A and Srivastava S, 2012. Effect of feeding bypass fat on intake and production performance of lactating crossbred cows. Indian J Anim Res, 46: 103-104

Naik PK, Saijpaul S, Sirohi AS and Raquib M, 2009. Lactation response of cross bred dairy cows fed indigenously prepared rumen protected fat - A field trial. Indian J Anim Sci, 79: 1045-1049

NRC 2001. Nutrient requirement of dairy cattle: Seventh revised edition, Washington, DC: The National Academies Press

Prasad J and Neeraj, 2010. Adaptation and its effects on animal. 6th edn., New Delhi: Kalyani Publisher, pp374

Ranjan A, Sahoo B, Singh VK, Srivastava S, Singh SP et al., 2009. Effect of bypass fat supplementation on productive performance and blood biochemical profile in lactating Murrah (Bubalus bubalis) buffaloes. Tropical Anim Health Prod, 44: 1615-1621

Sabuncuoglu N, 2004. Effect of barn types on physiological traits of calves. Indian Vet J, 81: 22-24

Savsani HH, Murthy KS, Padodara RJ, Bhadaniya AR and Kalaria V, 2013. Effect of bypass fat supplementation on haematology, growth and reproductive performance in Jaffrabadi buffaloes. Asian J Anim Sci, 8: 12-15

SejianV, 2013. Climate change: Impact on production and reproduction, adaptation mechanisms and mitigation strategies in small ruminants: A review. Indian J Small Rum, 1: 1-21

Schroeder GF, Gagliostro GA, Bargo F, Delahoy JE and Muller LD, 2004. Effects of fat supplementation on milk production and composition by dairy cows on pasture. Livestock Prod Sci, 86: 1-18

Silanikove N, 2000. Effects of heat stress on the welfare of extensively managed domestic ruminants. Livestock Prod Sci, 67(1): 1-18

Snedecor GW and Cochran WG, 1994. Statistical methods. $8^{\text {th }}$ edn., East West Press Private Limited, New Delhi

Tucker BC, Rogers AR,Verkerk GA, Kendall PE, Webster JR et al., 2007. Effects of shelter and body condition on the behaviour and physiology of dairy cattle in winter. Appl Anim Behaviour Sci, 105: 1-27

Wadhwa M, Grewal RS, Bakshi MPS and Brar PS, 2012. Effect of supplementing bypass fat on the performance of high yielding crossbred cows. Indian J Anim Sci, 82: 200-203

Waghmare SP, Meshram RB, Dakshinkar NP, Pajai KS and Siddiqui MF, 2016. Effect of supplementation of bypass fat on biochemical profilein dairy cows. Asian J Anim Sci, 11: 111-114

Yasothai R, 2014. Effect of climate on nutrient intake and metabolism and countering heat stress by nutritional manipulation. Int J Sci Env Technol, 3: $1685-1690$

Received - 02.04.2020, Accepted - 13.05.2020, Published - 01.06.2020 